\title{
ISOLASI DAN KARAKTERISASI FUNGI SELULOLITIK DARI TANAH GAMBUT CAGAR BIOSFER GIAM SIAK KECIL-BUKIT BATU, RIAU
}

\author{
Isolation and Characterization of Cellulolitic Fungi from Peat Swamp Biosphere Reservation Giak \\ Siak Kecil-Bukit Batu, Riau
}

\author{
*Rosa Devitria dan Harni Sepriyani \\ Akademi Analis Kesehatan Pekanbaru, Riau - Indonesia 28292 \\ Received 09 August 2018, Revised 18 October 2018, Accepted 16 November 2018
}

\begin{abstract}
Fungi is primary microorganism which produced cellulase enzyme. Cellulase was catalyzed cellulose from plants or organic waste in enzymatic reaction to be glucose, cellobiose and short polysaccharide. Cellulolytic fungi were isolated from Giam Siak Kecil-Bukit Batu (GSKBB) biosphere reserve. GSKBB is a natural peat swamp forest, with a peat bed reaching up to $9.2 \mathrm{~m}$. Peat swamp forest is a potential source for new species of fungi which produced cellulase in low pH and very good activity because peat swamp forest had been many cellulose and acid pH. Fungi strain was assigned as RHO1 at Aspergillus for genus based on microscopy analysis. Index cellulolytic of RHO1 was 2.31 and cellulase activity had values of $0.0125 \mathrm{U} / \mathrm{mL}$.
\end{abstract}

Keywords: Fungi, cellulase, peat swamp, biosphere, Giam Siak Kecil-Bukit Batu.

\section{Pendahuluan}

Fungi merupakan mikroorganisme utama yang dapat menghasilkan selulase yang mendegradasi selulosa amorf (fungi selulolitik). Selulase merupakan suatu enzim yang mampu menguraikan selulosa dengan cara menghidrolisis ikatan $\beta-1,4$ glikosidik menjadi bentuk yang lebih sederhana (Lynd, dkk., 2002). Fungi selulolitik dapat mengkatalisis secara enzimatis reaksi pembusukan selulosa yang berasal dari tumbuhan atau limbah yang mengandung bahan organik di alam menjadi glukosa, selobiosa, dan polisakarida yang lebih pendek (Eida, dkk., 2011; Acharya, dkk., 2008). Mikroorganisme yang mampu menghasilkan komponen selulase diantaranya adalah fungi Trichoderma, sehingga fungi ini sering disebut sebagai selulolitik sejati (Juhazs, dkk. 2005; Salma \& Gunarto, 1999). Suciatmih (2006) dalam penelitiannya mendapatkan fungi dari tanah hutan hujan tropis dengan jumlah terbanyak adalah Gongronell butleri, Cancellidium, Gelasinospora retispora, Gliocladium virens, Helicorhoidion dan Talaromyces wortmannii dengan jumlah terendah.

Cagar Biosfer Giam Siak Kecil-Bukit Batu (GSKBB) Provinsi Riau adalah bentangan hutan rawa gambut yang relatif masih alami yang merupakan cagar biosfer ketujuh yang ada di Indonesia serta menjadi bagian dari World Network of Biosphere (WNBR) UNESCO (Pratomo, 2010). Keunikan dari cagar biosfer ini adalah kedalaman gambutnya yang mencapai 9,2 m (Kobayashi, 2009). Gambut

*Correspondence:

Rosa Devitria

Akademi Analis Kesehatan Pekanbaru

e-mail: rosa.devitria@univrab.ac.id

Published by Universitas Tadulako 2018 merupakan pelapukan sisa tanaman berselulosa tinggi dan media tumbuh ideal bagi mikroorganisme penghasil selulase. Kondisi hutan gambut berpotensi untuk ditemukannya berbagai spesies baru dari fungi penghasil selulase berpH optimum rendah dengan aktivitas enzim yang tinggi, karena hutan gambut memiliki pH asam.

Penelitian ini bertujuan untuk mendapatkan spesies atau galur lokal baru, isolat fungi yang mampu mendegradasi selulosa, mengetahui aktivitas selulolitik masing-masing isolat fungi yang ditemukan dan mengkarakterisasi isolat fungi selulolitik dari tanah gambut Cagar Biosfer Giam Siak Kecil Bukit Batu Riau. Sehingga isolat fungi yang diperoleh dapat dijadikan bahan dasar pembuatan bioetanol yang merupakan sumber energi terbarukan saat ini.

Cagar Biosfer Giam Siak Kecil-Bukit Batu Provinsi Riau (GSKBB) merupakan satu-satunya konsep kawasan konservasi dan budidaya lingkungan yang diakui secara internasional, dengan demikian pengawasan dan pengembangan menjadi perhatian seluruh dunia atas kawasan tersebut (Sinaga, 2015). Tanah gambut ini merupakan penumpukan sisa tumbuhan yang mengalami dekomposisi yang tidak sempurna dan mempunyai kandungan bahan organik yang tinggi serta memiliki $\mathrm{pH}$ yang rendah (asam), namun pengalihan fungsi tanah gambut menjadi perkebunan menyebabkan kerusakan. Gambut di Sumatera relatif lebih subur dibandingkan dengan gambut di Kalimantan. Kandungan mineral gambut di Indonesia umumnya kurang dari 5\% dan sisanya adalah bahan organik. Fraksi organik terdiri dari senyawa-senyawa humat sekitar $10 \%$ hingga $20 \%$ dan sebagian besar lainnya adalah hemiselulosa, selulase, 
lignin dan senyawa lainnya (Agus \& Subiksa, 2008). Aktivitas mikroorganisme dalam tanah sangat dipengaruhi oleh beberapa faktor seperti iklim (curah hujan, angin dan suhu), tanah (keasaman, kelembaban, suhu, dan hara) dan vegetasi (hutan, padang rumput dan belukar), sehingga karena faktorfaktor tersebut sangat sulit untuk menduga jumlah, jenis dan aktivitas mikroorganisme (Yosmar, dkk., 2013)

Selulase merupakan senyawa polisakarida yang banyak terdapat di alam. Selulase termasuk enzim hidrolitik yang merupakan enzim ektstraseluler, teridir atas tiga komponen yaitu kompleks endo- $\beta$ 1,4-glukonase atau endogukonase, kompleks ekso- $\beta$ 1,4-glukonase atau eksoglukonase, dan $\beta-1,4$ gukosidase atau selobiase (Juhasz, dkk., 2005). Bobot molekulnya tinggi, strukturnya teratur berupa polimer yang linear terdiri dari unit ulangan $\beta$-DGlukosa. Karakteristik selulase antara lain muncul karena adanya struktur kristalin dan amorf serta pembentukan mikro fibril dan fibril yang pada akhirnya menjadi serat selulosa. Sifat selulase sebagai polimer tercermin dari bobot molekul rata-rata, polidispersitas dan konfigurasi rantainya (Lynd, dkk., 2002).

Menurut penelitian yang telah dilakukan oleh Subowo (2015) yaitu Isolasi dan Seleksi Fungi Tanah Pengurai Selulosa dari Berbagai Lingkungan, dimana pengambilan sampel tanah sebagai sumber fungi pengurai selulosa pada beberapa lingkungan berbeda yang terdapat di Kalimantan Barat, Bali dan Jawa Timur meliputi lingkungan gambut, lingkungan pantai, lingkungan mangrove, lingkungan tanah kering dan lingkungan perkebunan. Pada penelitian oleh Yosmar dkk., (2013) dengan judul Isolasi dan Uji Kualitatif Hidrolisat Fungi Penghasil Enzim Selulase dari Tanah Tumpukan Ampas Tebu, mendapatkan isolat fungi selulolitik dari tanah tumpukan ampas tebu yang sudah mengalami pelapukan di Tabek Patah Sumatera Barat.

Pencarian mikroorganisme yang mampu menghasilkan enzim-enzim komersial khususnya enzim selulase untuk produksi bioetanol perlu diupayakan sebagai salah satu bahan bakar alternatif yang diproduksi melalui proses fermentasi. Proses fermentasi dapat berlangsung dengan bantuan mikroorganisme, maka dari itu Cagar Biosfer Giam Siak Kecil-Bukit Batu Provinsi Riau yang terdiri dari tanah gambut akan diekplorasi dengan mencari mikroorganisme dari alam kita sendiri (Riyanti, 2009). Mikroorganisme selulase yang mampu menghasilkan selulosa yang berasal dari tanah gambut yaitu fungi karena memiliki daya pemecahan selulase lebih tinggi dari pada bakteri, terutama di tanah asam sehingga dapat digunakan dalam produksi bioetanol dan bidang industri lainnya (Purwoko, 2007).

Artikel ini mendeskripsikan isolasi dan karakterisasi fungi selulolitik dari tanah gambut cagar biosfer Giam Siak Kecil-Bukit Batu, Riau.

\section{Metode}

Penelitian ini dibagi atas beberapa tahap. Tahap pertama adalah pengambilan sampel tanah gambut yang diambil di hutan sekunder Cagar Biosfer GSKBB, Provinsi Riau. Tahap selanjutnya adalah isolasi fungi selulolitik dari sampel tanah tersebut pada medium padat selektif dengan sumber karbon tunggal khusus, yaitu karboksimetil selulosa (CMC). Koloni yang tumbuh dimurnikan pada medium selektif yang bersumber karbon CMC. Pemurnian dilakukan dengan pengenceran bertingkat dari suspensi spora yang disebar pada medium cawan petri, sehingga diperoleh koloni yang berasal dari spora tunggal. Setelah proses pemurnian, masing-masing kultur diidentifikasi secara morfologis dan ditentukan kemampuan tingkat produksi selulase secara kualitatif dan kuantitatif.

\section{Instrumen pelaksanaan \\ Alat}

Penelitian dilakukan di Laboratorium Akademi Analis Kesehatan Fajar. dan Laboratorium Biokimia Universitas Riau. Peralatan yang digunakan meliputi alat-alat gelas, Spektrofotometer; Autoklaf 1925x (Winconsin Aluminium Foundry Co. Inc., Monitowoc); Waterbath thermostat WK-24 (Sibata Scientific Technology Ltd); Rotary Shaker (Stuart Scientific Inggris); $\mathrm{pH}$ meter 2011; Vortex mixer Genie $2^{\text {TM }}$ Cat. No. 12-82; Kertas saring GF/C Whatman No. Katalog 1822055; mikroskop; dan peralatan biokimia standar lainnya sesuai dengan prosedur kerja.

\section{Bahan}

Bahan-bahan yang digunakan adalah $\mathrm{CMC}$ (karboksimetil selulosa) keluaran $\mathrm{BDH}$ Chemical Ltd Poole England (No. Katalog 27929), beberapa antibiotik yaitu nistatin (No. Katalog SIGMAAldrich N4014), klortetrasiklin (No. Katalog SIGMA-Aldrich C4881), penisilin G (produksi PT. Erela, Indonesia), neomisin sulfat (produksi PT. Sanbe, Indonesia), dan basitrasin (No. Katalog SIGMA-Aldrich B0125), serta bahan kimia 
proanalisis atau bahan preparatif sesuai prosedur kerja.

\section{Sumber sampel}

Sampel tanah diambil di tanah gambut Cagar Biosfer GSK-BB, Provinsi Riau. Pengambilan sampel dilakukan secara acak dari lima titik sampling pada kedalaman 1-15 cm dengan berat masing-masing tanah yaitu \pm 50 gram. Jarak satu titik sampling dengan titik sampling selanjutnya yaitu $\pm 100 \mathrm{~m}$. Sampel kemudian dimasukkan ke dalam kantung plastik, ditutup rapat, diberi label, disimpan dalam ice box, dan dibawa ke laboratorium untuk dilakukan isolasi fungi selulolitik.

\section{Pembuatan media}

a) Pembuatan medium selektif untuk isolasi fungi selulolitik

Medium selektif untuk isolasi fungi selulolitik dalam $1000 \mathrm{~mL}$ larutan terdiri dari: 1,00 gram $\mathrm{Ca}\left(\mathrm{NO}_{3}\right)_{2} ; \quad 0,26$ gram $\quad \mathrm{KNO}_{3} ; \quad 0,26$ gram $\mathrm{MgSO}_{4} \cdot 7 \mathrm{H}_{2} \mathrm{O} ; 0,12$ gram $\mathrm{KH}_{2} \mathrm{PO}_{4} ; 1,00$ gram $\mathrm{CaCl}_{2} \cdot 2 \mathrm{H}_{2} \mathrm{O} ; 20,0$ gram agar; 0,50 gram sodium propionat; 0,05 gram asam sitrat; 0,025 gram klortetrasiklin; 0,10 gram neomisin sulfat; 0,10 gram basitrasin; 0,10 gram penisilin G; 0,02 gram nistatin; $1 \mathrm{~mL}$ igepal 630; 2,00 gram CMC. Medium dimasukkan ke dalam Erlenmeyer, kemudian disterilisasi dengan autoklaf pada tekanan $15 \mathrm{lb}, 121$ ${ }^{\circ} \mathrm{C}$ selama 20 menit. Medium tersebut dituang pada cawan petri, kemudian diinkubasi pada suhu ruang.

\section{b) Pembuatan medium padat untuk analisis kualitatif selulase}

Medium untuk analisis pertumbuhan koloni selulase adalah modifikasi Wizna, dkk (2007) dibuat dalam $1000 \mathrm{~mL}$ larutan dengan komposisi yaitu: 200 gram kentang; $20 \mathrm{CMC}$; 17 gram agar. Medium padat bersumber CMC ini dipersiapkan sebagai berikut: ekstrak kentang sebanyak $300 \mathrm{~mL}$ dicampur dengan glukosa dan agar batang. Akuades ditambahkan hingga volume larutan menjadi 1000 $\mathrm{mL}$. Kemudian larutan dipanaskan hingga agar larut dan sterilisasi pada tekanan $15 \mathrm{lb}, 121^{\circ} \mathrm{C}$ selama 20 menit di dalam autoklaf. Kemudian medium dituang ke dalam cawan petri dan diinkubasi pada suhu ruang.

\section{c) Pembuatan medium cair untuk produksi selulase}

Medium cair yang digunakan untuk produksi enzim selulase adalah modifikasi dari Fekette, dkk (2007) dibuat dalam $1000 \mathrm{~mL}$ buffer asetat 0,05 M $\mathrm{pH} 5,5$ terdiri dari: 8 gram $\mathrm{NH}_{4} \mathrm{H}_{2} \mathrm{PO}_{4} ; 7$ gram $\mathrm{Na}_{2} \mathrm{HPO}_{4} ; 4$ gram $\mathrm{KH}_{2} \mathrm{PO}_{4} ; 1$ gram $\mathrm{CaCl}_{2} ; 1$ gram
$\mathrm{MgSO}_{4} ; 0,1$ gram pepton; $20 \mathrm{~mL}$ logam runut (250 $\mathrm{mg} \mathrm{FeSO}_{4} .7 \mathrm{H}_{2} \mathrm{O} ; 80 \mathrm{mg} \quad \mathrm{MnSO}_{4} \cdot \mathrm{H}_{2} \mathrm{O} ; 70 \mathrm{mg}$ $\mathrm{ZnSO}_{4}, 7 \mathrm{H}_{2} \mathrm{O}$ dalam $1 \mathrm{~L}$ akuades); dan 10 gram CMC. Medium cair ini dimasukkan ke dalam Erlenmeyer, kemudian disterilisasi dengan autoklaf pada tekanan $15 \mathrm{lb}, 121{ }^{\circ} \mathrm{C}$ selama 20 menit. Medium ini diinkubasi selama 24 jam pada suhu ruang sebelum digunakan.

\section{(4) Isolasi fungi selulolitik dari sampel tanah, pemurnian kultur, dan identifikasi morfologis}

Sampel tanah masing-masing sebanyak 0,6 gram dicampur menjadi satu dan disuspensi dalam $100 \mathrm{~mL}$ akuades steril, diaduk selama \pm 1 menit dengan menggunakan stirer. Sebanyak $1 \mathrm{~mL}$ suspensi diencerkan secara berseri. Masing-masing tingkat pengenceran diambil $0,1 \mathrm{~mL}$ suspensi dan disebarkan pada medium selektif, kemudian diinkubasi pada suhu ruang hingga koloni fungi tumbuh. Kolonikoloni fungi tunggal berspora hijau dipilih dan dipindahkan ke medium selektif dalam cawan petri untuk perbanyakan spora.

Pemurnian kultur dilakukan dengan metode pour plate. Spora yang telah lebat diambil dari permukaan medium menggunakan jarum ose dan dimasukkan ke tabung reaksi berisi air salin, serta dihomogenkan menggunakan vortex. Setelah homogen, suspensi tersebut disaring dengan glasswoll steril untuk memisahkan spora dari miselia dan diambil sebanyak $500 \mu \mathrm{L}$ filtrat untuk diencerkan secara berseri. Sebanyak $100 \mu \mathrm{L}$ dari masing-masing tabung diambil dan disebarkan pada medium selektif dalam cawan petri. Medium yang telah disebar spora diinkubasi pada suhu ruang. Kegiatan purifikasi diulang dua kali. Koloni yang berasal dari spora tunggal diharapkan telah murni. Fungi yang telah murni diidentifikasi di bawah mikroskop. Identifikasi dilakukan berdasarkan morfologisnya antara lain warna, ukuran dan bentuk fialospora, bentuk dan susunan fialida, dan morfologi miselia (Rifai, 1969).

\section{(5) Identifikasi morfologi dan mikroskopi fungi}

Fungi yang diamati morfologinya diinokulasi ke medium agar dalam cawan petri. Plug fungi berdiameter $1 \mathrm{~cm}$ diinkubasi pada suhu $30^{\circ} \mathrm{C}$. Pertumbuhan dan morfologi koloni fungi dicatat dan diamati.

Identifikasi mikroskopi fungi diamati menggunakan mikroskop. Fungi diinokulasi pada PDA yang dipotong berbentuk kubus dan diletakkan di atas kaca objek steril. Bagian atas PDA ditutup dengan kaca penutup steril. Preparat tersebut diletakkan di dalam petri yang telah disterilisasi 
sebelumnya. Dasar petri dialas dengan kertas saring steril yang telah dibasahi akuades steril. Fungi diinkubasi pada suhu kamar selama beberapa hari hingga tumbuh spora.

Kaca objek dibersihkan dengan alkohol 96\%, kemudian diteteskan laktofenol cotton blue pada permukaan kaca objek. Kaca penutup yang sudah ditumbuhi spora diambil dengan hati-hati, letakkan di atas kaca objek, serap kelebihan laktofenol dengan kertas saring. Preparat diperiksa di bawah mikroskop dengan perbesaran kecil, kemudian tingkatkan ke perbesaran yang lebih kuat.

\section{(6) Produksi selulase}

Spora dari koloni fungi di cawan petri dilepaskan dari media, disuspensi dalam larutan salin dan disaring dengan glass wool steril. Spora fungi selulolitik diinokulasi ke medium produksi enzim $\mathrm{pH}$ 5,5. Kultur cair ini diinkubasi pada suhu ruang ( 30 $\left.{ }^{\circ} \mathrm{C}\right)$ dengan meletakkan dalam rotary shaker dengan kecepatan 150 rpm selama 5 hari. Enzim dipisahkan dari fungi menggunakan sentrifugasi dalam keadaan dingin dengan kecepatan $9500 \mathrm{rpm}$ selama 10 menit. Supernatan disaring dengan filter glass fiber (Whatman $G F / C)$ dan disterilisasi dengan filter polysulfone 0,45 $\mu \mathrm{m}$.

\section{(7) Produksi selulase}

Produksi selulase dari fungi ditentukan dengan metode Nelson-somogyi. Absorbansi larutan diukur dengan spektrofotometer sinar tampak pada panjang gelombang $540 \mathrm{~nm}$ (Clark \& Switzer, 1977). Satu unit aktivitas aviselase atau selulase didefinisikan sebagai banyaknya enzim yang melepaskan $1 \mu \mathrm{mol}$ gula pereduksi permenit.

\section{Hasil dan Pembahasan}

\section{Identifikasi makroskopis dan mikroskopis fungi}

Berdasarkan isolasi fungi dari tanah di Cagar Biosfer GSKBB telah berhasil diisolasi satu isolat fungi. Fungi tersebut diberi kode galur RH01. Analisis makroskopis dilihat berdasarkan morfologi fungi. Morfologi isolat RH01 dilakukan untuk identifikasi awal fungi yang telah berhasil diisolasi pada Gambar 1. Identifikasi morfologi dilihat berdasarkan bentuk dan warna fungi. Identifikasi mikroskopis dilakukan untuk melihat hifa, konidia atau spora, dan konidiofor untuk menentukan genus dari fungi. Hasil analisis mikroskopis mengindikasikan bahwa isolat RH01 termasuk ke dalam genus Aspergilus. Aspergillus secara makroskopis bertekstur seperti kapas, berwarna putih dan putih kekuning-kuningan. Secara mikroskopis hifa bersekat, konidia bulat hingga lonjong, konidiofor tidak bercabang dan memperbesar ujungnya membentuk vesikel yang membengkak (Larone dan Honig, 2002). Hasil analisis secara mikroskopis dapat dilihat pada Gambar 2.

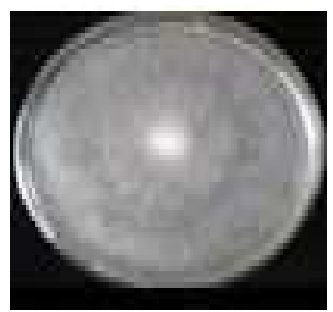

Gambar 1. Isolat fungi RH01

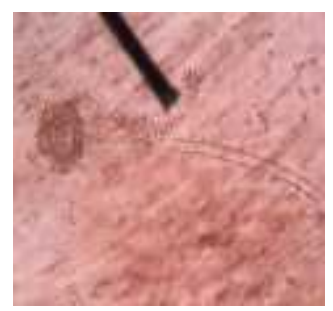

Gambar 2. Identifikasi mikroskopis isolat fungi RH01

Hasil identifikasi makroskopis dan mikroskopis dari isolat fungi RH01 dapat dilihat pada Tabel 1.

Tabel 1. Hasil identifikasi makroskopis dan mikroskopis isolat fungi RH01

\begin{tabular}{|c|c|c|c|}
\hline Isolat & Makroskopis & Mikroskopis & Keterangan \\
\hline RH01 & $\begin{array}{l}\text { Bentuk bulat, } \\
\text { tekstur kasar } \\
\text { dan berbutir, } \\
\text { berwarna putih. }\end{array}$ & $\begin{array}{l}\text { hifa bersekat, } \\
\text { konidia bulat } \\
\text { hingga lonjong, } \\
\text { konidiofor tidak } \\
\text { bercabang dan } \\
\text { memperbesar } \\
\text { ujungnya } \\
\text { membentuk } \\
\text { vesikel yang } \\
\text { membengkak. }\end{array}$ & Aspergillus \\
\hline
\end{tabular}

Isolat fungi RH01 diisolasi pada medium selektif bersumber karbon CMC (Carboxy Methyl Celluloce). CMC merupakan turunan selulosa yang mudah larut dalam air, oleh karena itu CMC mudah dihidrolisis menjadi gula-gula sederhana oleh enzim selulase. Produksi enzim selulase dari isolat fungi RH01 dilakukan analisis secara kualitatif dan kuantitatif. Analisis secara kualitatif ditentukan berdasarkan timbulnya zona bening pada medium agar yang telah ditambahkan pewarnaan congo red. Congo red akan 
bergabung dengan ikatan glikosida dari selulase, selanjutnya selulase yang dihasilkan akan memutus ikatan glikosida tersebut sehingga terbentuk zona bening di sekitar koloni fungi (Yoon, dkk, 2007). Zona bening yang timbul pada medium agar menunjukkan bahwa fungi memproduksi enzim selulase yang dinyatakan dalam indeks selulolitik. Indeks selulolitik dari isolat fungi RH01 sebsesar 2,31. Zona bening pada medium agar yang mengandung congo red dapat dilihat pada Gambar 3.

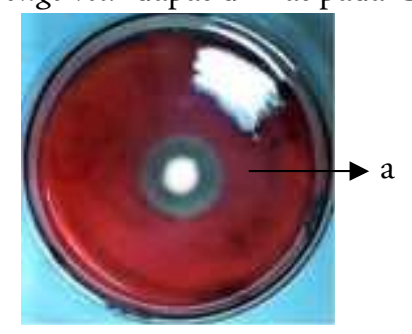

Gambar 3. Zona bening (a) isolat fungi RH01

Kemampuan isolat fungi RH01 menghasilkan enzim selulase secara kuantitatif dilakukan menggunakan metode Nelson-somogyi. Metode ini melibatkan dua tahap reaksi yaitu reaksi antara Dglukosa dengan reagen Nelson yang menghasilkan produk $\mathrm{Cu}_{2} \mathrm{O}$ berupa endapan merah bata dan reaksi yang kedua adalah reaksi antara $\mathrm{Cu}_{2} \mathrm{O}$ dengan reagen arsenomolibdat. Metode ini dapat digunakan untuk mengukur gula pereduksi, semakin tinggi konsentrasi gula maka warna yang terbentuk akan semakin pekat. Hasil pengukuran aktivitas enzim selulase dari isolat fungi RH01 dapat dilihat pada Tabel 2.

Tabel 2. Aktivitas enzim selulase isolat fungi RH01

\begin{tabular}{|c|c|c|c|c|}
\hline \multirow{2}{*}{ Isolat } & \multicolumn{2}{|c|}{$\begin{array}{l}\text { Konsentrasi gula } \\
\text { pereduksi }(\mu \mathrm{mol} / \mathrm{mL})\end{array}$} & \multirow{2}{*}{$\begin{array}{c}\text { Aktivitas } \\
\text { enzim } \\
(\mathrm{U} / \mathrm{mL})\end{array}$} & \multirow{2}{*}{$\begin{array}{c}\text { Rerata } \\
\text { aktivitas } \\
\text { enzim } \\
(\mathrm{U} / \mathrm{mL})\end{array}$} \\
\hline & Kontrol & Uji & & \\
\hline \multirow{2}{*}{ RH01 } & \multirow{2}{*}{0,144} & 0,557 & 0,013 & \multirow{2}{*}{0,0125} \\
\hline & & 0,555 & 0,012 & \\
\hline
\end{tabular}

Aktivitas enzim selulase ditentukan sebagai jumlah gula pereduksi yang dilepaskan oleh enzim persatuan waktu. Satu unit aktivitas selulase didefinisikan sebagai banyaknya enzim yang melepaskan $1 \mu \mathrm{mol}$ gula pereduksi permenit. Aktivitas enzim dapat dipengaruhi oleh panas, asam, basa, pelarut organik atau keadaan-keadaan lain yang dapat menyebabkan denaturasi protein. Enzim selulase memiliki aplikasi yang luas. Selulase sangat potensial digunakan dalam industri makanan, makanan hewan, tekstil, bahan bakar, kimia, pulp and paper, pengolahan limbah, obat dan farmasi, produksi protoplas, dan penanggulangan polusi (Acharya dkk., 2008).

\section{Kesimpulan}

Fungi selulolitik telah berhasil diisolasi dari tanah gambut hutan Cagar Biosfer GSKBB dan diberi kode galur RH01. Berdasarkan analisis makroskopis dan mikroskopis, isolat fungi $\mathrm{RH} 01$ termasuk ke dalam genus Aspergilus. Kemampuan isolat fungi RH01 dalam memproduksi enzim selulase ditentukan secara kualitatif dan kuantitatif. Analisis kualitatif dilakukan memalui indeks selulolitik yaitu 2,31 dan analisis kuantitatif memalui penntuan aktivitas enzim selulase yaitu sebesar $0,0125 \mathrm{U} / \mathrm{mL}$

\section{Ucapan Terima kasih}

Penulis mengucapkan terimakasih kepada Kopertis Wilayah X dan Kementrian Riset dan Teknologi Pendidikan Tinggi melalui Direktorat Jendral Riset dan Pengabdian Masyarakat atas dana hibah yang diberikan kepada penulis melalui dana Penelitian Dosen Pemula tahun 2018.

\section{Referensi}

Acharya, P. B., Acharya, \& Modi, H. A. (2008). Optimization for cellulase production by aspergillus niger using saw dust as substrate. African Journal of Biotechnology, 22, 4147-4152.

Agus, F. \& Subiksa, I. G. M. (2008). Lahan gambut potensi untuk pertanian dan aspek lingkungan. Bogor: Balai Penelitian Tanah dan World Agroforestry Centre (ICRAF).

Clark, J. M., \& Switzer, R. L. (1977). Experimental biochemistry. $2^{\text {nd }}$ ed. San Fransisco: W. H. Freeman \& Co.

Eida, M. F., Nagaoka, T., Wasaki, J., \& Kouna, K. (2011). Evaluation of cellulolytic and hemicellulolytic abilities of fungi isolated from coffee residue and sawdust composts. Microbes and Envinronments, 26, 220-227.

Juhazs, T., Szengyel, Z., Reczey, K., Siika-Aho, M., \& Viikari, L. (2005). Characterization of cellulases and hemicellulases produced by Trichoderma reesei on various carbon sources. Process Biochemistry, 40(11), 3519-3525.

Kobayashi, S. (2009). Ecological of peat swam forest and land resource management option for global-warming prevention in Southeast Asian wetlands. dalam: International Workshop Scientific Exploration and Sustainable Management of Peat Land Resources in Giam Siak Kecil-Bukit Batu Biosphere Reserve, Riau. Pekanbaru. 21-27. 
Lynd, L. R., Weimer, P. J., Vanzyl, W. H., \& Pretorius, I. S. (2002). Microbial cellulose utilization: fundamentals and biotechnology. Microbiology and Molecular Biology Reviews, 66(3), 506-577.

Pratomo, B. M. (2010). Cagar biosfer giam siak warisan riau untuk dunia. Media Indonesia, 16.

Purwoko. (2007). Fisiologi mikroba. Jakarta: Bumi Aksara.

Salma S., \& Gunarto, L. (1999). Enzim selulase dari Trichoderma sp. Buletin Agro Bio, 2, 9-16.

Suciatmih. (2006). Soil fungi in an over-burned tropical rain forest in Bukit Bangkirai, East Kalimantan. Biodiversitas, 7(1), 1-3.

Riyanti, I. E. (2009). Biomassa sebagai bahan baku bioetanol. Jurnal Penelitian dan Pengembangan Pertanian, 28(3), 101-110.
Sinaga, A. N. (2015). Kerjasama Jepang-Indonesia melalui japan international corporation agency (JICA) di Cagar Biosfer Giam Siak Kecil-Bukit Batu, Kabupaten Bengkalis. Jurnal Online Mahasiswa FISIP, 2(1), 1-14.

Subowo, Y. B. (2015). Isolasi dan seleksi jamur tanah pengurai selulosa dari berbagai lingkungan. Prosiding Seminar Nasional Masyarakat Biodiversitas Indonesia, 1(3), 423-427.

Yoon, J. H., Park, . E., Suh, D. Y., Hong, S. B., Ko, S. J., \& Kim, S. H. (2007). Comparison of dyes for easy detection of extracellular cellulases in fungi. Mycobiology, 35(1), 21-24.

Yosmar, R., Suharti, N., \& Rasyid, R. (2013). Isolasi dan uji kualitatif hidrolisat jamur penghasil enzim selulase dari tanah tumpukan ampas tebu. Jurnal Farmasi Andalas, 1(1), 5-12. 